medRxiv preprint doi: https://doi.org/10.1101/2020.04.09.20059006; this version posted April 11, 2020. The copyright holder for this preprint

(which was not certified by peer review) is the author/funder, who has granted medRxiv a license to display the preprint in perpetuity.

It is made available under a CC-BY-ND 4.0 International license.

\title{
Effectiveness of quarantine measure on transmission dynamics of COVID-19 in Hong Kong
}

Hsiang-Yu Yuan ${ }^{1}$, Axiu Mao ${ }^{2}$, Guiyuan Han $^{1}$, Hsiangkuo Yuan ${ }^{3}$, Dirk Pfeiffer ${ }^{4}$

1 Department of Biomedical Sciences

Jockey Club College of Veterinary Medicine and Life Sciences

City University of Hong Kong

Hong Kong, China

2 Department of Infectious Diseases and Public Health

Jockey Club College of Veterinary Medicine and Life Sciences

City University of Hong Kong

Hong Kong, China

3 Department of Neurology

Thomas Jefferson University Hospital

Philadelphia, PA, US

4 Centre for Applied One Health Research and Policy Advice

City University of Hong Kong

Hong Kong, China

Correspondence to Hsiang-Yu Yuan: sean.yuan@cityu.edu.hk

NOTE: This preprint reports new research that has not been certified by peer review and should not be used to guide clinical practice. 
medRxiv preprint doi: https://doi.org/10.1101/2020.04.09.20059006; this version posted April 11, 2020. The copyright holder for this preprint (which was not certified by peer review) is the author/funder, who has granted medRxiv a license to display the preprint in perpetuity. It is made available under a CC-BY-ND 4.0 International license.

\begin{abstract}
The rapid expansion of COVID-19 has caused a global pandemic. Although quarantine measures have been used widely, the critical steps among them to suppress the outbreak without a huge social-economic loss remain unknown. Hong Kong, unlike other regions in the world, had a massive number of travellers from Mainland China during the early expansion period, and yet the spread of virus has been relatively limited. Understanding the effect of control measures to reduce the transmission in Hong Kong can improve the control of the virus spreading.

We have developed a susceptible-exposed-infectious-quarantined-recovered (SEIQR) meta-population model that can stratify the infections into imported and subsequent local infections, and therefore to obtain the control effects on transmissibility in a region with many imported cases. We fitted the model to both imported and local confirmed cases with symptom onset from 18 January to 29 February 2020 in Hong Kong with daily transportation data and the transmission dynamics from Wuhan and Mainland China.

The model estimated that the reproductive number was dropped from 2.32 to 0.76 (95\% CI, 0.66 to 0.86 ) after an infected case was estimated to be quarantined half day before the symptom onset, corresponding to the incubation time of 5.43 days (95\% CI, 1.30-9.47). If the quarantine happened about one day after the onset, community spread would be likely to occur, indicated by the reproductive number larger than one. The results suggest that the early quarantine for a suspected case before the symptom onset is a key factor to suppress COVID-19.
\end{abstract}


medRxiv preprint doi: https://doi.org/10.1101/2020.04.09.20059006; this version posted April 11, 2020. The copyright holder for this preprint (which was not certified by peer review) is the author/funder, who has granted medRxiv a license to display the preprint in perpetuity.

It is made available under a CC-BY-ND 4.0 International license.

\section{Introduction}

The coronavirus SARS-CoV-2 outbreak, originally occurred from Wuhan, China, in December 2019 has caused a global pandemic in March 2020 [1,2]. Regions in East Asia, such as Hong Kong, Taiwan, Korea and Japan, all faced an extremely high risk of community outbreak due to a massive number of travellers from Mainland China during the Chinese new year [3,4]. However, comparing to many other countries until now (March 2020), the coronavirus outbreak was still considered limited in Hong Kong and Taiwan [5]. The low number of transmission can be due to a successful public health control strategy. To understand how coronavirus can be contained in these places is of great importance to limit the global spread of the virus happening right now.

Presently, nonpharmaceutical interventions including both mitigation and suppression strategies have been proposed to control the outbreak [6]. Suppression strategies were often intensive that can be challenging to fully implemented in many countries such as transportation restriction or city lockdown [4,7]. How Hong Kong successfully prevent the outbreak without shutting down most of the public services thus offers us a different perspective on how to choose a containing strategy.

As most countries, quarantine and border control policies were taken in order to stop the spread of the coronavirus 16 from Wuhan. During the Chinese New Year festival, which started on 24 January in 2020, more than one million of travellers (some were Hong Kong residents) arrived Hong Kong from Mainland in a week [8]. Local spread 17 occurred starting from this critical moment when only few initial travellers who carried the disease. Therefore, infected individuals were reported almost every day with travel history from Wuhan or Mainland China from 18 January 2020 until 4 February 2020, when most of the border crossings were closed [9]. After 28 January, most the travellers from Mainland require 14 days self-quarantine. Quarantine and border control were the major control measures performed during this period in Hong Kong.

Assessing the effect of quarantine measures during this period in Hong Kong may provide an opportunity to 25 understand how an outbreak can be suppressed (indicated by a reproductive number below one), by quarantine 26 measures without extremely intensive interventions. However, challenge exists in assessing the effect on trans- 27 missibility in Hong Kong using classical transmission models, such as susceptible-infectious-recovered (SIR) or susceptible-exposed-infectious-recovered (SEIR) models, because many confirmed cases were identified as 29 imported cases. To obtain the reproductive number, an indication of the transmissibility of the virus, the num- 30 ber of secondary infections of a given infected individual should be estimated. However, with many imported 31 
medRxiv preprint doi: https://doi.org/10.1101/2020.04.09.20059006; this version posted April 11, 2020. The copyright holder for this preprint (which was not certified by peer review) is the author/funder, who has granted medRxiv a license to display the preprint in perpetuity.

It is made available under a CC-BY-ND 4.0 International license.

cases, the observed changes in numbers of cumulative cases are not totally due to those secondary infections

happened locally. Because current models cannot distinguish the imported and local infections, overestimation of the reproductive number can be easily happened.

In order to estimate the reproductive number and other epidemiological parameters of COVID-19 in Hong Kong, here we developed a susceptible-exposed-infected-quarantined-recovered (SEIQR) meta-population model em37 bedded with passenger data from Mainland China, that can stratify imported and local cases. We used Hong 38 Kong as an example to demonstrate that the model can successfully recapture the transmission dynamics of both 39 imported and local infections and estimate the reproductive number. Furthermore, the minimum timing and 40 intensity of quarantine to suppress the outbreak were estimated. 
medRxiv preprint doi: https://doi.org/10.1101/2020.04.09.20059006; this version posted April 11, 2020. The copyright holder for this preprint (which was not certified by peer review) is the author/funder, who has granted medRxiv a license to display the preprint in perpetuity.

It is made available under a CC-BY-ND 4.0 International license .

\section{Materials \& Methods}

\section{Data collection}

We collected the date of symptom onset time for each daily newly infected case of COVID-19 from 18 January to 29 February 2020 in Hong Kong from the Centre for Health Protection, Government of the Hong Kong Special Administrative [10]. Number of daily newly infected COVID-19 cases in Wuhan City and Mainland China outside Wuhan from 16 January to 29 February 2020 were collected from the National Health Commission of China [11]. Daily passenger data from Mainland China during the corresponding period were obtained from the Hong Kong Immigration Department [12].

\section{SEIQR Meta-population model}

The meta-population model was fitted first to the data from Wuhan and Mainland China (outside Wuhan). Using the reconstructed transmission dynamics from source regions, the model was next fitted to the confirmed cases with symptom onset in Hong Kong with transportation data. Assuming the newly emergence of COVID-19 causes an outbreak at location $i$, during the emergence, the changes of the numbers of infectious cases $I_{j}$ at a different location $j$ can be determined using a meta-population framework with a mobility matrix (contact mixing at the population level) such that $I_{j}=I_{j_{-i m p}}+I_{j_{-} l o c}$, where the subscripts $i m p$ and $l o c$ represent imported and local cases and the number of $I_{j_{-} i m p}$ is dependent on the mobility matrix. We developed an SEIQR model to include dynamics of both imported and local cases at a target location (Hong Kong), and linked this model to the meta-population framework:

$$
\begin{gathered}
\frac{d S}{d t}=-\beta \frac{S}{N}\left(I_{i m p}+I_{l o c}+q Q_{i m p}+q Q_{l o c}\right) \\
\frac{d E_{i m p}}{d t}=E_{i m p W}^{+}+E_{i m p C}^{+}-\frac{1}{\tau} E_{i m p} \\
\frac{d I_{i m p}}{d t}=\frac{1}{\tau} E_{i m p}-\frac{1}{T_{q r}} I_{i m p}-\gamma I_{i m p} \\
\frac{d Q_{i m p}}{d t}=\frac{1}{T_{q r}} I_{i m p}-\gamma Q_{i m p} \\
\frac{d R_{i m p}}{d t}=\gamma\left(I_{i m p}+Q_{i m p}\right)
\end{gathered}
$$

$$
\frac{d E_{l o c}}{d t}=\beta \frac{S}{N}\left(I_{i m p}+I_{l o c}+q Q_{i m p}+q Q_{l o c}\right)-\frac{1}{\tau} E_{l o c}
$$


medRxiv preprint doi: https://doi.org/10.1101/2020.04.09.20059006; this version posted April 11, 2020. The copyright holder for this preprint (which was not certified by peer review) is the author/funder, who has granted medRxiv a license to display the preprint in perpetuity. It is made available under a CC-BY-ND 4.0 International license .

$$
\begin{gathered}
\frac{d I_{l o c}}{d t}=\frac{1}{\tau} E_{l o c}-\frac{1}{T_{q r}} I_{l o c}-\gamma I_{l o c} \\
\frac{d Q_{l o c}}{d t}=\frac{1}{T_{q r}} I_{l o c}-\gamma Q_{l o c} \\
\frac{d R_{l o c}}{d t}=\gamma\left(I_{l o c}+Q_{l o c}\right)
\end{gathered}
$$

where $\beta$ is the transmission rate, $\tau$ is the latent periods, $\gamma$ is the recovery rate, $T q r$ is the time to quarantine after being infectious and $q$ is the recontact ratio of quarantined to unquarantined individuals. $I_{i m p}, I_{l o c}, Q_{i m p}, Q_{l o c}$ are the infectious imported cases, infectious local cases, infectious imported cases that are under quarantined and infectious local cases that are under quarantined. Please see Table 1 and Table 2 for detailed definitions of each variables and parameters. Our SEIQR meta-population model stratifies the imported and local cases and is embedded with border control and quarantine measures given daily passenger data from Wuhan and Mainland China. $E_{i m p W}^{+}$and $E_{i m p C}^{+}$are the daily newly number of imported cases from Wuhan (denoted as $W$ ) and Mainland China outside Wuhan (denoted as $C$ ). These numbers are determined by the daily passenger numbers and incubation period:

$$
\begin{gathered}
E_{i m p W}^{+}=\eta M_{H W} \beta \frac{S_{W}}{N_{W}} \frac{I_{W}}{R_{p t}} \\
E_{i m p C}^{+}=\eta M_{H C} \beta \frac{S_{C}}{N_{C}} \frac{I_{C}}{R_{p t}}
\end{gathered}
$$

where $M_{j i}$ is the mobility rate from $i$ to $j$, subscripts $H, W, C$ indicates Hong Kong, Wuhan, Mainland China (outside Wuhan), respectively. We used daily passenger data from the source regions divided by the population size in the source regions to refer to $M_{j i}$ (Table S1). Among all the passengers from Mainland China, the proportion of them coming from Wuhan to Hong Kong during the study period can be calculated using the International Air Transport Association (IATA) database [13]. We estimated 2.92\% of the total passenger from Mainland China to Hong Kong was from Wuhan. We assumed only the patients without symptom onset can pass the border to Hong Kong. Thus the terms $\beta \eta M_{H W} \frac{S_{W}}{N_{W}} \frac{I_{W}}{R_{p t}}$ and $\beta \eta M_{H C} \frac{S_{C}}{N_{C}} \frac{I_{C}}{R_{p t}}$ represent the daily newly 83 imported cases from Wuhan and Mainland China (outside Wuhan) where $\eta$ is a function to calculate the number 84 of infected cases before symptom onset [14] and $R_{p t}$ is the reporting ratio.

\section{Transmission dynamics in source regions}

To obtain the number of imported cases, the model has to generate the transmission dynamics $\left(I_{W}\right.$ and $\left.I_{C}\right) \quad 88$ at source regions and estimated the imported cases using transportation data. We used a simple SIR model to 
medRxiv preprint doi: https://doi.org/10.1101/2020.04.09.20059006; this version posted April 11, 2020. The copyright holder for this preprint (which was not certified by peer review) is the author/funder, who has granted medRxiv a license to display the preprint in perpetuity.

It is made available under a CC-BY-ND 4.0 International license .

Table 1: Descriptions of variables in the meta-population model.

\begin{tabular}{l|l} 
Variables & Descriptions \\
\hline$N$ & Population size in Hong Kong \\
$S$ & Susceptible cases \\
$E_{i m p}$ & Exposed imported cases \\
$I_{i m p}$ & Infectious imported cases \\
$Q_{i m p}$ & Quarantined infectious imported cases \\
$R_{i m p}$ & Recovered imported cases \\
$E_{l o c}$ & Exposed local cases \\
$I_{l o c}$ & Infectious local cases \\
$Q_{l o c}$ & Quarantined infectious local cases \\
$R_{l o c}$ & Recovered local cases \\
\hline$N_{W}$ & Population size in Wuhan \\
$S_{W}$ & Susceptible cases in Wuhan \\
$I_{W}$ & Infected cases in Wuhan \\
$N_{C}$ & Population size in Mainland China (non-Wuhan) \\
$S_{C}$ & Susceptible cases in Mainland China (non-Wuhan) \\
$I_{C}$ & Infected cases in Mainland China (non-Wuhan)
\end{tabular}

construct newly infected numbers that reproduced the same numbers of cumulative confirmed cases in Wuhan and Mainland China (outside Wuhan) after the outbreak. Please see supplementary methods for the detailed 91 descriptions.

\section{Parameter estimation}

Prior to parameter estimation, the transmission dynamics in Wuhan and non-Wuhan Mainland China were reconstructed using a modified SIR model. The resulting source dynamics were used as an initial condition to seed imported cases for the target region (Figure S1 and Figure S2). Second, the posterior distributions of the parameters of transmission dynamics in Hong Kong were obtained using Markov Chain Monte Carlo (MCMC) to fit the detected infected cases from the model to the reported cases with symptom onset. The posterior distributions were obtained from Metropolis-Hastings in Markov Chain Monte Carlo (MCMC) with $1.2 \times 10^{6}$ steps (Figure S3 and Figure S4) to guarantee an effective sample size (ESS) of greater than 200 for all parameters. The Gelman-Rubin convergence diagnostic was used and all the scores were less than 1.056 and near one, which confirmed the convergence.

Prior distributions for all the parameters were set to uniform distributions except the generation time $T c$ and the recontact ratio $q$. The prior of the generation time was assumed to be normally distributed with mean set to be 7.95 days, the average from two previous studies [15,16]. The standard deviation was 0.25 . The mean 105 recontact ratio of being quarantined and not quarantined in a Gaussian prior was set to be $12 \%$ with a standard $\quad 106$ deviation of 0.05 . A recent study has estimated each individual can contact 12.5 persons on average during a 107 
medRxiv preprint doi: https://doi.org/10.1101/2020.04.09.20059006; this version posted April 11, 2020. The copyright holder for this preprint (which was not certified by peer review) is the author/funder, who has granted medRxiv a license to display the preprint in perpetuity.

It is made available under a CC-BY-ND 4.0 International license .

day [17]. Assuming many self-quarantine individuals can likely contact to their household members, with a possible expected number 1.5 persons, the mean recontact ratio of quarantined individuals to unquarantined in the prior distribution can thus be determined as $q=\frac{1.5}{12.5}$.

The likelihood of observing onset dates of both confirmed imported and confirmed local cases in Hong Kong 113 were calculated based on Poisson distribution during MCMC. Newly detected infected cases are defined as the newly infected cases with symptom onset that eventually became quarantined. We assumed all the confirmed cases were quarantined. The daily newly detected imported cases with symptom onset was used as the expected value of the Poisson distribution and can be derived as $\Delta I_{i m p}(\sigma) D$, where $\Delta I_{i m p}=\frac{1}{\tau} E_{i m p}$, and $D$ is the detection ratio, which was defined as the proportion of the number of quarantined imported cases to the total number of infectious and quarantined cases. $\sigma$ represents the pre-symptomatic transmission period, which produced a 119 delay of onset after an individual has been infected. The same approach can be used to determine the expected value of the Poisson distribution for the detected local cases.

\section{Effective reproductive number calculation}

The effective reproductive number $R_{e}$, was calculated using the next-generation matrix approach after obtaining the posterior distributions of model parameters [18]. Please see supplementary methods for the detailed descriptions. 
medRxiv preprint doi: https://doi.org/10.1101/2020.04.09.20059006; this version posted April 11, 2020. The copyright holder for this preprint (which was not certified by peer review) is the author/funder, who has granted medRxiv a license to display the preprint in perpetuity.

It is made available under a CC-BY-ND 4.0 International license .

\section{Results}

Our meta-population model reproduced the COVID-19 transmission dynamics of both imported and local infections in Hong Kong. The number of cumulative imported cases was increasing rapidly in Hong Kong after the first imported case was detected, with onset day on 18 January 2020 until the end of Chinese New Year in early February (Figure 1A). The risk of community spread was highlighted as the number of local cases crossed above the imported cases. In order to understand the transmission dynamics of COVID-19 in Hong Kong, we developed an SEIQR meta-population model that stratifies imported and local cases (Figure 2). The model recaptured the cumulative numbers with a crossover between the local and imported cases (Figure $1 \mathrm{~B}$ ) and transient dynamics (Figure 3). The predicted number of imported cases reached to a peak on 26 January (Figure 3A). These imported cases immediately caused a wave of local infections. The number of daily newly detected local cases reached to a peak around 2 February and decreased afterward (Figure $3 \mathrm{~B}$ ).

Epidemiological parameters of COVID-19 were obtained for Hong Kong from 18 January to 29 February. The effective reproductive number $R_{e}$ was $0.76(0.66-0.86)$ (Table 2). $R_{0}$ was $2.32(1.19-4.42)$, referring to the reproductive number when the quarantine measure was not included. Latent period was 1.94 days $(0.34$ - 4.17). The pre-symptomatic transmission period before disease onset was 3.49 days $(0.48-5.80)$. The incubation time was calculated as 5.43 days (1.30 - 9.47), consistent with recent findings, where a mean or median incubation period of approximately 5 days was reported [16,19,20]. We assumed all the infected persons can pass the border before disease onset, which was defined as the incubation time. The estimated time to quarantine after being infectious $T_{q r}$ in Hong Kong is 2.92 days (0.65 - 7.81) days, which is nearly two days less than the incubation period. The recontact ratio of quarantined to unquarantined individuals $q$ was $10.26 \%(5.32-17.8)$. The model estimated only $22 \%(9-41)$ of total infected cases were documented in Mainland China.

The timing of quarantine was an important measurement to determine the risk of community spread. The estimated $T_{q r}$ in Hong Kong was about half day earlier than the symptom onset time and was able to reduce $R_{e}$ to 154 be less than one (Figure $4 \mathrm{~A}$ ). If $T_{q r}$ was longer than one day after disease onset, $R_{e}$ became greater than one, the 155 community spread could happen. Furthermore, the recontact ratio of quarantined to unquarantined individuals 156 affected the value of $R_{e}$. If the $q$ became about two and a half larger than the estimated value, $R_{e}$ was greater 

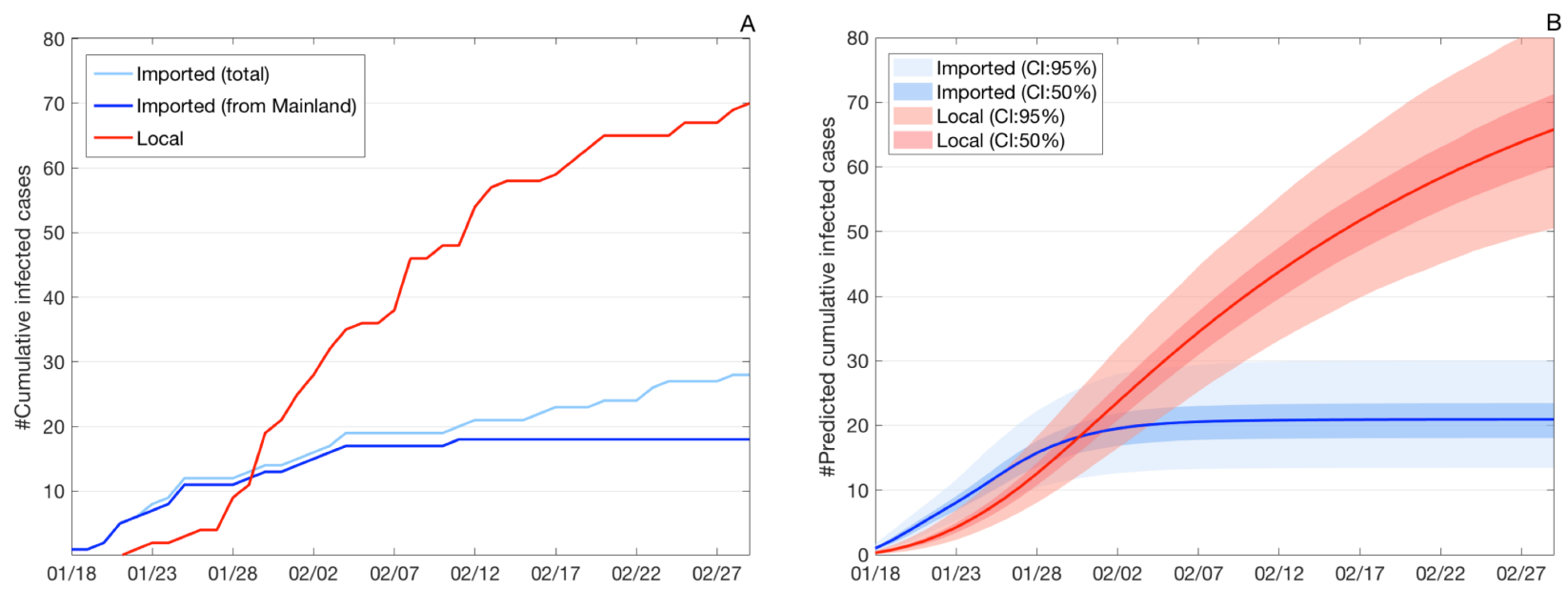

Figure 1 Number of cumulative confirmed COVID-19 cases by symptom onset date. (A) Observed cumulative confirmed cases. Light blue denotes the total imported cases. Dark blue denotes the imported cases only from China, excluding few other cases mainly from diamond princess cruise. Red denotes the local cases. (B) Predicted cumulative detected cases. Blue denotes the predicted number of cumulative detected imported cases from China. Red denotes the predicted number of cumulative detected local cases. Solid lines indicate the mean values.

than one and the community spread could also happen (Figure 4B). The epidemiological parameters and the effects of quarantine measures during an infection generation was illustrated (Figure 5). Sensitivity analysis has been performed to evaluate the impact of initial setting of generation time to the effective reproductive number. For sensitivity analysis, we have tested two alternative model settings, with the generation time fixed at 7.5 or 8.4 days. Both of the settings gave the mean $R e$ of 0.76 or 0.77 as well.

\section{Effects of quarantine on Detection Ratio}

The results showed that the ratio can be low during the initial period but soon reached saturated values after 3 weeks both for imported and local cases (Figure 6 $\mathrm{AB}$ ). Generally the detection ratios of the imported cases were higher than the local cases because the number of the imported cases were low. For local cases, 71\%(46-90) of which were detected, estimated by our model. One day delay of quarantine reduced about $10 \%$ of daily detection ratio to $60 \%(39-74)$ (Figure 6B). Only 31\%(20 - 39) of them could be detected or quarantined if quarantine was delayed 6 days. The results showed that not only early quarantine can reduce reproductive number, but also has a benefit on increasing overall detection ratio. 
medRxiv preprint doi: https://doi.org/10.1101/2020.04.09.20059006; this version posted April 11, 2020. The copyright holder for this preprint (which was not certified by peer review) is the author/funder, who has granted medRxiv a license to display the preprint in perpetuity. It is made available under a CC-BY-ND 4.0 International license .

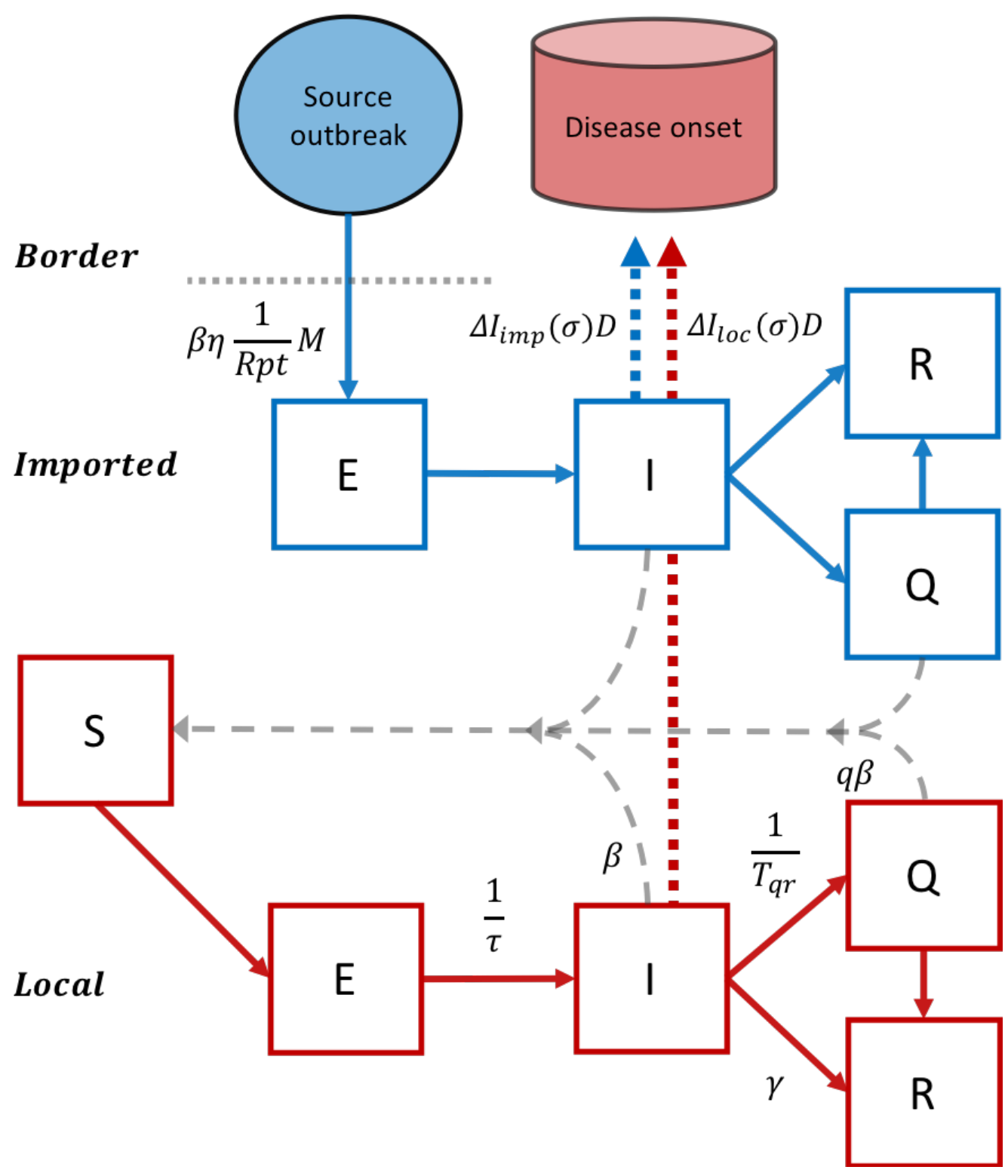

Figure 2 Schema of susceptible-exposed-infected-quarantined-recovered meta population model. Imported cases arrive as exposed (E) status before disease onset in order to pass through the border. Imported cases then become infectious $(\mathrm{I})$, quarantined $(\mathrm{Q})$ or recovered $(\mathrm{R})$ statuses. $\beta \eta \frac{1}{R_{p t}} M$ is the rate to produce imported cases, where $\eta$ is a function to determine the probability of an ill passenger can pass the border (see Methods for the details). $R_{p t}$ is the reporting ratio in Mainland China and $M$ is the mobility rate. Both imported and local cases are able to infect susceptible individuals ( $\mathrm{S}$ ) and cause local transmission while quarantined cases have a lower transmission rate depending on the recontact ratio $(q)$, indicating the ratio of the contact rates of quanratined to unquarantined individuals. Epidemiological parameters $\beta$ is the transmission rate, $\tau$ is the latent periods, $\gamma$ is the recovery rate, $T_{q r}$ is the time to quarantine after being infectious. $\Delta I_{i m p}(\sigma) D$ represents the newly detected imported cases, where $D$ is the detected ratio defined as the ratio of the number of quarantined imported cases to the total number of infectious and quarantined imported cases, and $\sigma$ is the pre-symptomatic transmission period, indicating the delayed time of symptom onset after being infectious. Similarly, $\Delta I_{l o c}(\sigma) D$ represents the detected local cases. 
medRxiv preprint doi: https://doi.org/10.1101/2020.04.09.20059006; this version posted April 11, 2020. The copyright holder for this preprint (which was not certified by peer review) is the author/funder, who has granted medRxiv a license to display the preprint in perpetuity.

It is made available under a CC-BY-ND 4.0 International license .
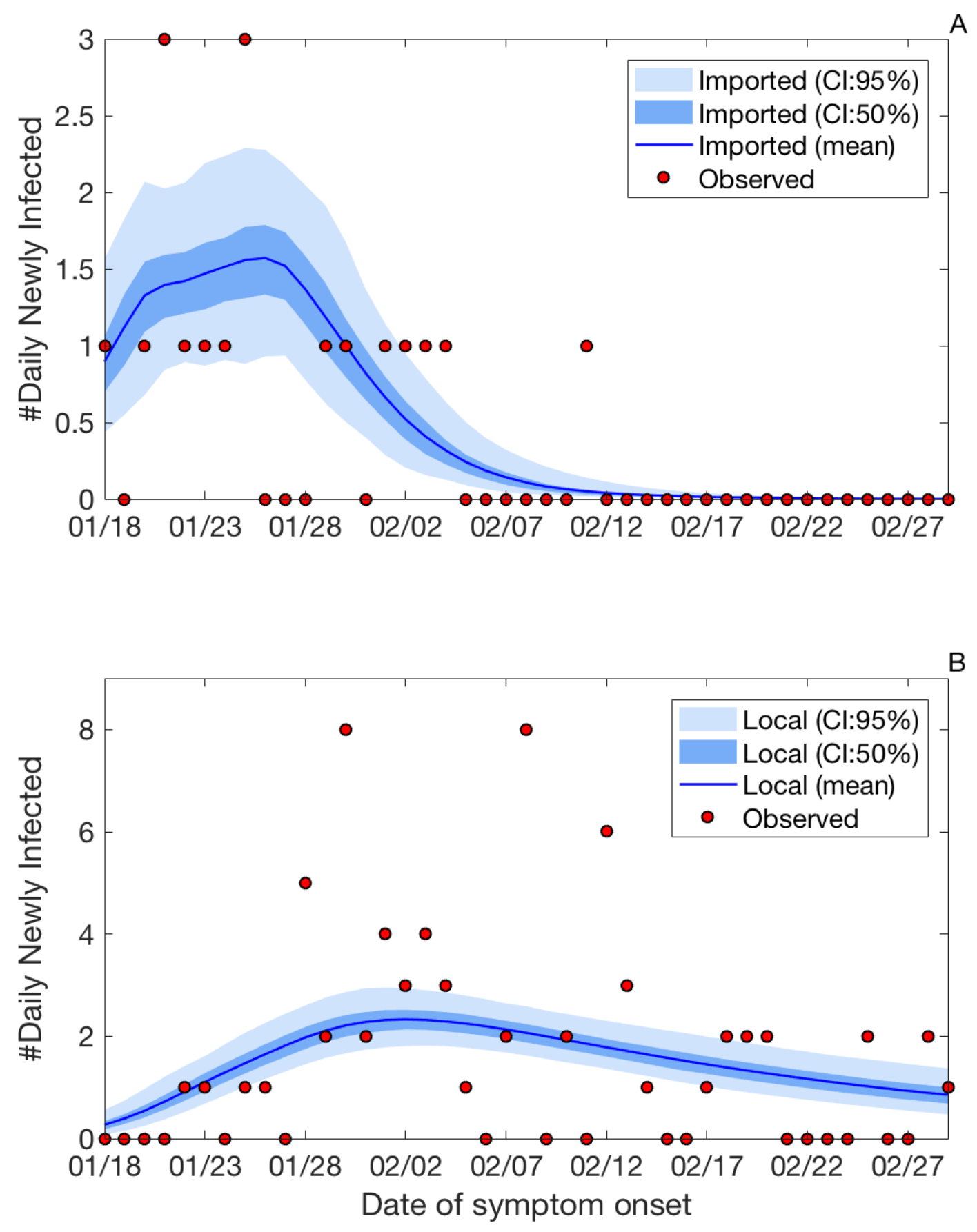

Figure 3 Observed and predicted numbers of detected imported and local cases. (A) Number of observed imported and predicted number of detected imported cases. Mean, $50 \%$ and $95 \%$ prediction intervals are shown. The predicted detected cases are the daily newly cases with symptom onset that eventually become quarantined and detected. (B) Number of observed local and predicted number of detected local cases. Mean, $50 \%$ and $95 \%$ prediction intervals are shown. The definition of the detected local cases is same as (A) but for local infections. 
medRxiv preprint doi: https://doi.org/10.1101/2020.04.09.20059006; this version posted April 11, 2020. The copyright holder for this preprint (which was not certified by peer review) is the author/funder, who has granted medRxiv a license to display the preprint in perpetuity.

It is made available under a CC-BY-ND 4.0 International license .
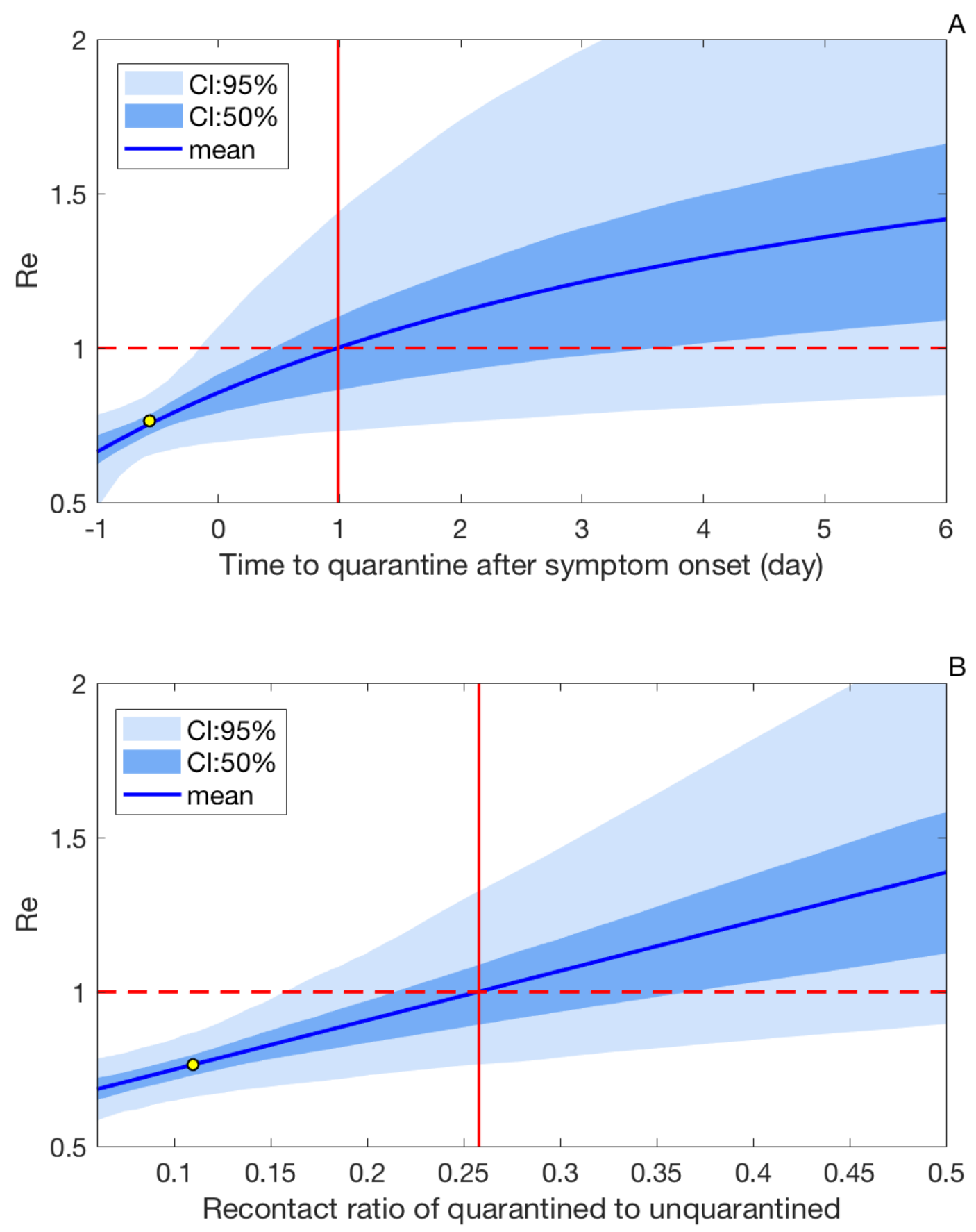

Figure 4 Effective reproductive numbers by different timings and intensities of quarantine measures. (A) The mean and credible intervals of effective reproductive number $R_{e}$ by different days of time to quarantine $T_{q r}$. Note the values were adjusted to time to quarantine after symptom onset. The vertical line corresponds to the average time from onset to isolation when $R_{e}$ is one. Dashed line indicates the level of $R_{e}$ as one. Yellow dot represents the estimated $T_{q r}$ and the corresponded $R_{e}$. (B) The mean and credible intervals of effective reproductive number $R_{e}$ by recontact ratios $q$. Yellow dot represents the estimated $T_{q r}$ and the corresponded $R_{e}$. All the values were estimated from 2000 random samples from posterior distributions. 
medRxiv preprint doi: https://doi.org/10.1101/2020.04.09.20059006; this version posted April 11, 2020. The copyright holder for this preprint (which was not certified by peer review) is the author/funder, who has granted medRxiv a license to display the preprint in perpetuity.

It is made available under a CC-BY-ND 4.0 International license .

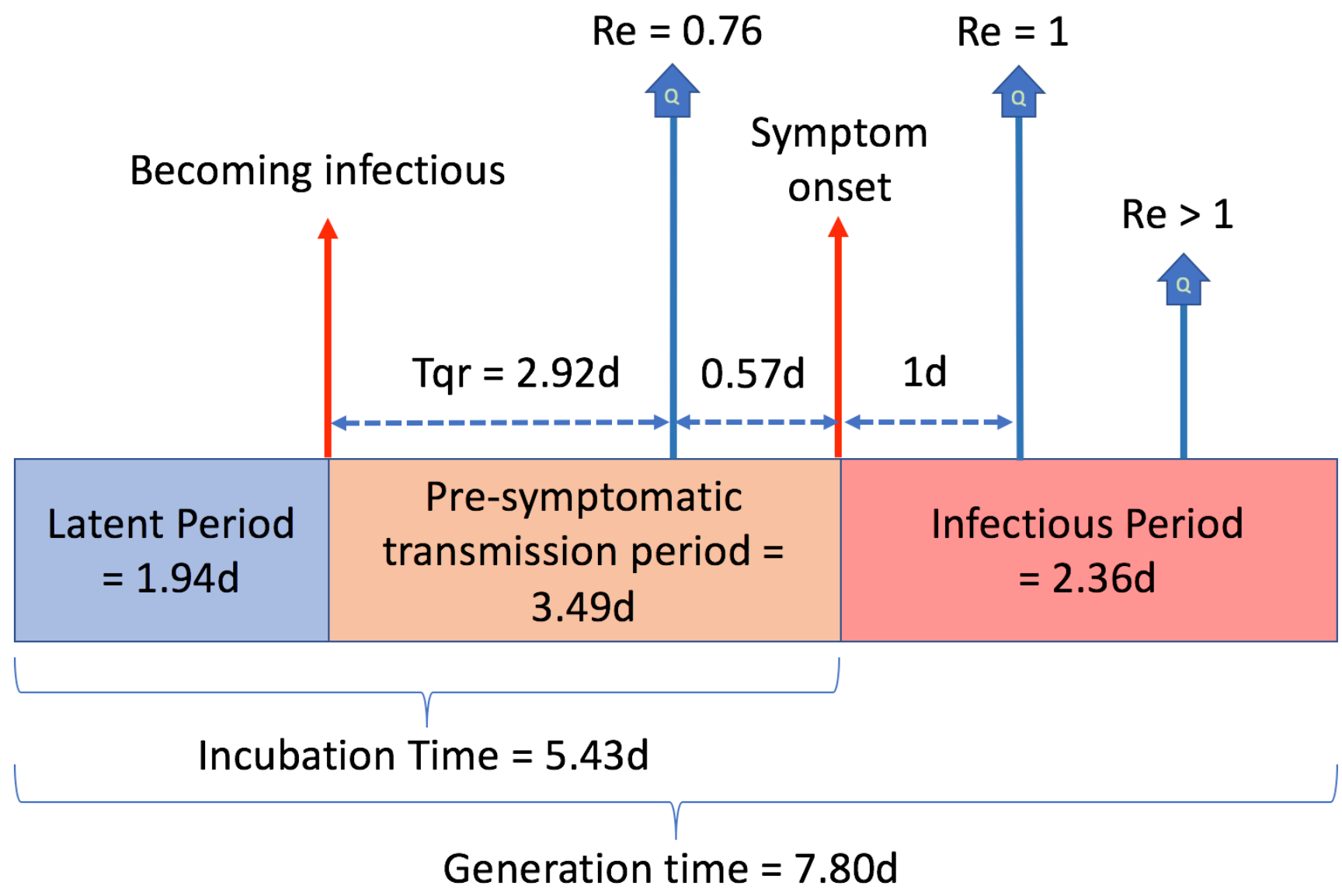

Figure 5 Epidemiological parameters during an infection generation. The effects of different times to quarantine on the effective reproductive number are illustrated.

Table 2: Values of reproductive numbers and other epidemiological parameters of COVID-19 in Hong Kong. Mean values with $95 \%$ credible intervals are produced. The basic reproductive number is defined as the expected number of secondary infections without quarantine. The effective reproductive number is derived from the posterior variables when quarantine measure is considered. The incubation time inc refers to the sum of latent period $\tau$ and pre-symptomatic transmission period $\sigma$.

\begin{tabular}{l|l|l} 
Parameters & Values & Descriptions \\
\hline$R_{e}$ & $0.76(0.66-0.86)$ & Effective reproductive number \\
$R_{0}$ & $2.32(1.19-4.42)$ & Basic reproductive number (without quarantine measure) \\
inc & $5.43(1.30-9.47)$ & Incubation time (unit: day) \\
$\tau$ & $1.94(0.34-4.17)$ & Latent period (unit: day) \\
$\sigma$ & $3.49(0.48-5.80)$ & Pre-symptomatic transmission period (unit: day) \\
$T c$ & $7.80(6.81-8.79)$ & Generation time (unit: day) \\
$T_{q r}$ & $2.92(0.65-7.81)$ & Time to quarantine after being infectious (unit: day) \\
$q$ & $10.26 \%(5.32-17.8)$ & Recontact ratio of quarantined to unquarantined \\
$R p t$ & $22 \%(9-41)$ & Reporting ratio in Mainland China \\
\hline
\end{tabular}


medRxiv preprint doi: https://doi.org/10.1101/2020.04.09.20059006; this version posted April 11, 2020. The copyright holder for this preprint (which was not certified by peer review) is the author/funder, who has granted medRxiv a license to display the preprint in perpetuity.

It is made available under a CC-BY-ND 4.0 International license .
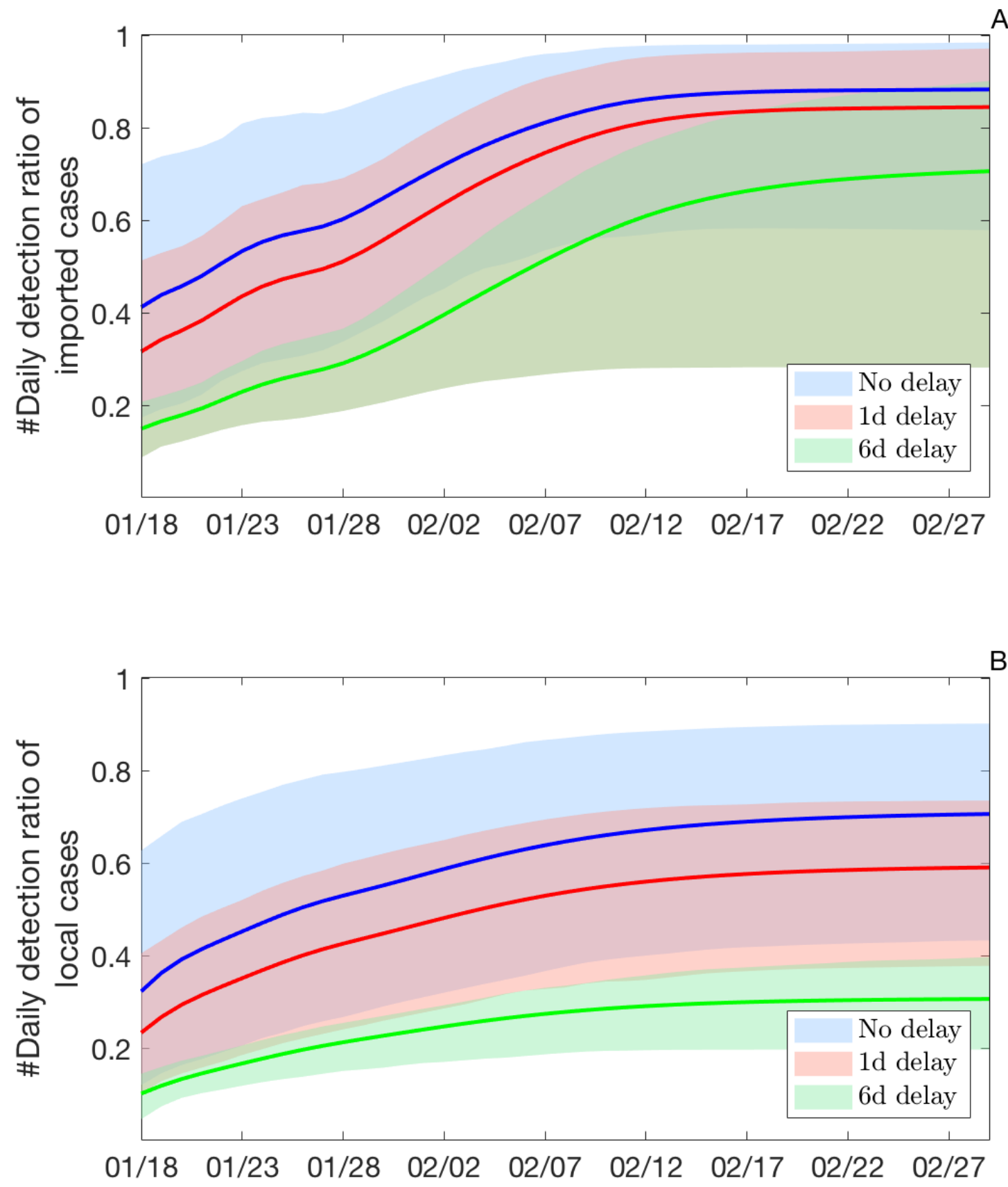

Figure 6 Detection ratios of imported and local cases by time. (A) Detection ratios of imported cases. The ratios denote the proportion of daily newly cases with symptom onset that eventually become quarantined among all infectious cases. Blue, the detection ratio estimated using the posterior distribution of the time to quarantine, denoted as no delay. Red, the detection ratio estimated using the posterior distribution of the time to quarantine with one day delay. Green, the detection ratio estimated using the posterior distribution of the time to quarantine with six days delay. Shared areas are the $95 \%$ intervals. (B) Detection ratios of local cases. The ratios denote the proportion of daily newly cases with symptom onset that eventually become quarantined among all infectious cases. Same definition of colors are used as (A) but for local infections. 
medRxiv preprint doi: https://doi.org/10.1101/2020.04.09.20059006; this version posted April 11, 2020. The copyright holder for this preprint (which was not certified by peer review) is the author/funder, who has granted medRxiv a license to display the preprint in perpetuity.

It is made available under a CC-BY-ND 4.0 International license .

\section{Discussion}

By characterizing the transmission dynamics with quarantine and border control measures across the Chinese

New Year festival in Hong Kong, we have identified the key aspects in containing the outbreak. This is the first 175 study to demonstrate that early time targeted quarantine measures significantly suppress the COVID-19 outbreak 176 and the proper timing of quarantine is feasible. Suppression of the outbreak during the study period is important 177 because global expansion occurred starting from this critical moment when initial travellers who carried the 178 diseases moved to different countries [21-24].

Until now, how to suppress the outbreak of COVID-19 has been studied only in regions with many infections, 181 such as Wuhan or China [4, 21, 25, 26]. Although certain strict public health policies can suppress the outbreak, 182 these approaches can cause profound social and economic impacts, which may not be feasible by every country. 183 In contrast, our study illustrated that Hong Kong can be a good model to learn how to prevent the community 184 spread through quarantine before many other intensive control policies (such as transportation restriction and 185 closure of public facilities) are required.

How to impose a large scale quarantine properly to suppress the outbreak remain largely unknown [6]. Our results demonstrated that quarantine of suspected individuals before symptom onset, is critical to contain the COVID-19 outbreak. Given that the incubation period was about 5 days and the confirmation of COVID-19 infection can often be delayed, to guarantee an early quarantine of all suspected cases before symptom onset is a critical criterion to reduce the chance of community spread.

Using a model that can stratify both dynamics of imported and local infections, we demonstrated that many epidemiological parameters, including the reproductive number, latent period and incubation time, along with the reporting ratio in Mainland China can be estimated after fitting confirmed cases with symptom onset in Hong Kong with daily transportation data. Generation time we used are adopted from previous studies studies with the estimated mean of 7.8 days [15,16]. The values, such as incubation time and reporting ratio are consistent to recent studies [7, 16, 19,20].

One of the major challenges to limit the COVID-19 epidemic through quarantine is pre-symptomatic trans- 201 mission. Currently, little is known about when does the transmission occur before the symptom. Our model 202 has found, an individual after latent period, can be infectious without symptoms about 3 days, similar to 1-3 203 
medRxiv preprint doi: https://doi.org/10.1101/2020.04.09.20059006; this version posted April 11, 2020. The copyright holder for this preprint (which was not certified by peer review) is the author/funder, who has granted medRxiv a license to display the preprint in perpetuity.

It is made available under a CC-BY-ND 4.0 International license .

days found by many recent studies through contact tracing and enhanced investigation of clusters of confirmed cases [27,-30]. Thus, even if a very intensive contact tracing is proposed, to identify all the contacts made by an infectious individual before symptom onset can be difficult. Thus, how to reduce social contacts and maintain 206 social distancing along with quarantine measures become critical to prevent the spread. To evaluate the bene- 207 fits of different approaches to reduce unnecessary contacts, such as working from home, wearing masks, etc, 208 becomes an important task [31,32]. 209

The study highlights the importance of having a time targeted quarantine measure along with travel bans. Investigating the timing and the quality of quarantine in different outbreak regions is a critical factor for prevention 212 and control of COVID-19 outbreak.

Declaration of Interests 215

$\begin{array}{ll}\text { All authors declare no competing interests. } & 216\end{array}$

$\begin{array}{ll}\text { Acknowledgments } & 218\end{array}$

We thank Prof. Steven Riley from MRC Centre for Global Infectious Disease Analysis at Imperial College Lon- 219 don to give valuable comments. We thank Prof. Mengsu (Michael) Yang, Dr. Xin Wang, and Dr. Kai Liu from 220 City University of Hong Kong, Prof. Kin On Kwok from Chinese University of Hong Kong, Prof. Dong-Ping 221 Wang from Stony Brook University, Dr. Lindsey Wu from London School of Hygiene and Tropical Medicine, 222 and all the anonymous readers who have provided invaluable comments. The authors also acknowledge the 223 support from the grants funded by City University of Hong Kong [\#7200573 and \#9610416]. 224

\section{Author Contributions}

H-YY designed the study. AM and GH participated in the data collection. H-YY and AM analysed and interpreted the data. H-YY wrote the paper. Everyone reviewed, revised and edited the manuscript. 
medRxiv preprint doi: https://doi.org/10.1101/2020.04.09.20059006; this version posted April 11, 2020. The copyright holder for this preprint (which was not certified by peer review) is the author/funder, who has granted medRxiv a license to display the preprint in perpetuity. It is made available under a CC-BY-ND 4.0 International license.

\section{References}

[1] Chaolin Huang, Yeming Wang, Xingwang Li, Lili Ren, Jianping Zhao, Yi Hu, Li Zhang, Guohui Fan, Jiuyang Xu, Xiaoying Gu, et al. Clinical features of patients infected with 2019 novel coronavirus in Wuhan, China. The Lancet, 395(10223):497-506, 2020.

[2] Fan Wu, Su Zhao, Bin Yu, Yan-Mei Chen, Wen Wang, Zhi-Gang Song, Yi Hu, Zhao-Wu Tao, Jun-Hua Tian, Yuan-Yuan Pei, et al. A new coronavirus associated with human respiratory disease in China. Nature, 579(7798):265-269, 2020.

[3] Yuan-Chien Lin, Wan-Ju Chi, Yu-Ting Lin, and Chun-Yeh Lai. The spatiotemporal estimation of the dynamic risk and the international transmission of 2019 novel coronavirus (COVID-19) outbreak: A global perspective. medRxiv, 2020.

[4] Huaiyu Tian, Yonghong Liu, Yidan Li, Chieh-Hsi Wu, Bin Chen, Moritz UG Kraemer, Bingying Li, Jun Cai, Bo Xu, Qiqi Yang, et al. The impact of transmission control measures during the first 50 days of the COVID-19 epidemic in China. medRxiv, 2020.

[5] Hong Kong Centre for Health Protection. Countries/areas with reported cases of coronavirus disease-2019 (COVID-19), updated on April 8, 2020.

[6] Neil Ferguson, Daniel Laydon, Gemma Nedjati Gilani, Natsuko Imai, Kylie Ainslie, Marc Baguelin, Sangeeta Bhatia, Adhiratha Boonyasiri, Zulma Cucunuba Perez, Gina Cuomo-Dannenburg, et al. Report 9: Impact of non-pharmaceutical interventions (NPIs) to reduce COVID19 mortality and healthcare demand. 2020 .

[7] Jingbo Liang and Hsiang-Yu Yuan. The impacts of diagnostic capability and prevention measures on transmission dynamics of COVID-19 in Wuhan. medRxiv, 2020.

[8] Simiao Chen, Juntao Yang, Weizhong Yang, Chen Wang, and Till Bärnighausen. COVID-19 control in China during mass population movements at New Year. The Lancet, 395(10226):764-766, 2020.

[9] Hong Kong Government. Arrivals down. https://www.news.gov.hk/eng/2020/02/ 20200207/20200207_185633_805.html.

[10] Hong Kong Centre for Health Protection. The latest situation of COVID-19 confirmed cases in HK, updated on April 8, 2020. https://www.chp.gov.hk/files/pdf/local_situation_covid19_ tc.pdf 
medRxiv preprint doi: https://doi.org/10.1101/2020.04.09.20059006; this version posted April 11, 2020. The copyright holder for this preprint (which was not certified by peer review) is the author/funder, who has granted medRxiv a license to display the preprint in perpetuity.

It is made available under a CC-BY-ND 4.0 International license .

[11] National Health Commission of China. Novel coronavirus outbreak data. http://www.nhc.gov.cn/ xcs/yqtb/list_gzbd.shtml.

[12] Hong Kong Immigration Department. Statistics on passenger traffic. https://www.immd.gov.hk/ eng/message_from_us/stat_menu.html.

[13] International Air Transport Association. Air traffic statistics. https://www.iata.org/en/ services/statistics/air-transport-stats/.

[14] M. Pear Hossain, Alvin Junus, Xiaolin Zhu, Pengfei Jia, Tzai-Hung Wen, Dirk Pfeiffer, and Hsiang-Yu Yuan. The effects of border control and quarantine measures on global spread of COVID-19. medRxiv, 2020.

[15] Marc Lipsitch, Ted Cohen, Ben Cooper, James M Robins, Stefan Ma, Lyn James, Gowri Gopalakrishna, Suok Kai Chew, Chorh Chuan Tan, Matthew H Samore, et al. Transmission dynamics and control of severe acute respiratory syndrome. Science, 300(5627):1966-1970, 2003.

[16] Qun Li, Xuhua Guan, Peng Wu, Xiaoye Wang, Lei Zhou, Yeqing Tong, Ruiqi Ren, Kathy SM Leung, Eric HY Lau, Jessica Y Wong, et al. Early transmission dynamics in Wuhan, China, of novel coronavirusinfected pneumonia. New England Journal of Medicine, 2020.

[17] Kin On Kwok, Ben Cowling, Vivian Wei, Steven Riley, and Jonathan M Read. Temporal variation of human encounters and the number of locations in which they occur: a longitudinal study of Hong Kong residents. Journal of The Royal Society Interface, 15(138):20170838, 2018.

[18] Odo Diekmann, JAP Heesterbeek, and Michael G Roberts. The construction of next-generation matrices for compartmental epidemic models. Journal of the Royal Society Interface, 7(47):873-885, 2010.

[19] Stephen A. Lauer, Kyra H. Grantz, Qifang Bi, Forrest K. Jones, Qulu Zheng, Hannah R. Meredith, Andrew S. Azman, Nicholas G. Reich, and Justin Lessler. The incubation period of coronavirus disease 2019 (COVID-19) from publicly reported confirmed cases: estimation and application. Annals of Internal Medicine, 032020.

[20] Natalie M Linton, Tetsuro Kobayashi, Yichi Yang, Katsuma Hayashi, Andrei R Akhmetzhanov, Sung-mok Jung, Baoyin Yuan, Ryo Kinoshita, and Hiroshi Nishiura. Incubation period and other epidemiological characteristics of 2019 novel coronavirus infections with right truncation: a statistical analysis of publicly available case data. Journal of Clinical Medicine, 9(2):538, 2020. 
medRxiv preprint doi: https://doi.org/10.1101/2020.04.09.20059006; this version posted April 11, 2020. The copyright holder for this preprint (which was not certified by peer review) is the author/funder, who has granted medRxiv a license to display the preprint in perpetuity. It is made available under a CC-BY-ND 4.0 International license.

[21] Moritz UG Kraemer, Chia-Hung Yang, Bernardo Gutierrez, Chieh-Hsi Wu, Brennan Klein, David M Pigott, Louis du Plessis, Nuno R Faria, Ruoran Li, William P Hanage, et al. The effect of human mobility and control measures on the COVID-19 epidemic in China. Science, 2020.

[22] Matteo Chinazzi, Jessica T. Davis, Marco Ajelli, Corrado Gioannini, Maria Litvinova, Stefano Merler, Ana Pastore y Piontti, Kunpeng Mu, Luca Rossi, Kaiyuan Sun, Cécile Viboud, Xinyue Xiong, Hongjie Yu, M. Elizabeth Halloran, Ira M. Longini, and Alessandro Vespignani. The effect of travel restrictions on the spread of the 2019 novel coronavirus (COVID-19) outbreak. Science, 2020.

[23] Chad R. Wells, Pratha Sah, Seyed M. Moghadas, Abhishek Pandey, Affan Shoukat, Yaning Wang, Zheng Wang, Lauren A. Meyers, Burton H. Singer, and Alison P. Galvani. Impact of international travel and border control measures on the global spread of the novel 2019 coronavirus outbreak. Proceedings of the National Academy of Sciences, 117(13):7504-7509, 2020.

[24] Chi Chiu Leung, Tai Hing Lam, and Kar Keung Cheng. Mass masking in the COVID-19 epidemic: people need guidance. The Lancet, 395(10228):945, 2020.

[25] Joseph T Wu, Kathy Leung, and Gabriel M Leung. Nowcasting and forecasting the potential domestic and international spread of the 2019-nCoV outbreak originating in Wuhan, China: a modelling study. The Lancet, 395(10225):689-697, 2020.

[26] Adam J Kucharski, Timothy W Russell, Charlie Diamond, Yang Liu, John Edmunds, Sebastian Funk, Rosalind M Eggo, Fiona Sun, Mark Jit, James D Munday, et al. Early dynamics of transmission and control of COVID-19: a mathematical modelling study. The Lancet Infectious Diseases, 2020.

[27] Ping Yu, Jiang Zhu, Zhengdong Zhang, and Yingjun Han. A familial cluster of infection associated with the 2019 novel coronavirus indicating possible person-to-person transmission during the incubation period. The Journal of Infectious Diseases, 2020.

[28] Zhen-Dong Tong, A Tang, KF Li, P Li, HL Wang, JP Yi, YL Zhang, and JB Yan. Potential presymptomatic transmission of SARS-CoV-2, Zhejiang Province, China, 2020. Emerging infectious diseases, 26(5), 2020.

[29] Wycliffe E Wei. Presymptomatic transmission of SARS-CoV-2-Singapore, January 23-March 16, 2020. Morbidity and Mortality Weekly Report, 69, 2020.

[30] Anne Kimball. Asymptomatic and presymptomatic SARS-CoV-2 infections in residents of a long-term care skilled nursing facility-King County, Washington, March 2020. Morbidity and Mortality Weekly 
medRxiv preprint doi: https://doi.org/10.1101/2020.04.09.20059006; this version posted April 11, 2020. The copyright holder for this preprint (which was not certified by peer review) is the author/funder, who has granted medRxiv a license to display the preprint in perpetuity. It is made available under a CC-BY-ND 4.0 International license .

Report, 69, 2020.

[31] Nancy HL Leung, Daniel KW Chu, Eunice YC Shiu, Kwok-Hung Chan, James J McDevitt, Benien JP Hau, Hui-Ling Yen, Yuguo Li, Dennis KM Ip, JS Malik Peiris, et al. Respiratory virus shedding in exhaled breath and efficacy of face masks. Nature Medicine, pages 1-5, 2020.

[32] Christina Atchison, Leigh Bowman, Jeffrey W Eaton, Natsuko Imai, Rozlyn Redd, Philippa Pristera, Charlotte Vrinten, and Helen Ward. Report 10: Public response to UK Government recommendations on COVID-19: population survey, 17-18 March 2020. 
medRxiv preprint doi: https://doi.org/10.1101/2020.04.09.20059006; this version posted April 11, 2020. The copyright holder for this preprint

(which was not certified by peer review) is the author/funder, who has granted medRxiv a license to display the preprint in perpetuity.

It is made available under a CC-BY-ND 4.0 International license .

\section{Supplementary Methods}

\section{Dynamics in source regions}

To obtain the number of imported cases, the model has to generate transmission dynamics in source regions is to seed the target region (Hong Kong). We modified an SIR to construct newly infected numbers that were close to the observed confirmed numbers in Wuhan and Mainland China (outside Wuhan).

$$
\begin{gathered}
\frac{d S_{i}}{d t}=-\beta \frac{S_{i}}{N_{i}}-E_{i m p i}^{+}-\alpha S_{i} \\
\frac{d I_{i}}{d t}=\beta \frac{S_{i}}{N_{i}}-\gamma I_{i} \\
\frac{d R_{i}}{d t}=\gamma I_{i}
\end{gathered}
$$

Where $\alpha$ is a parameter to represent the effect of reduction of social contacts after the Wuhan lockdown on 23 January 2020 and the closure of the border crossings on 4 February 2020 [1]. As a result, reduction of susceptible population happens by time. Assuming generation time is 8.4 days thus we have the recovery rate $\gamma=\frac{1}{8.4}$. Using $R_{0}=2.92$, we can obtain $\beta=R_{0} \gamma=0.3476$ in Mainland China. We also assumed the recovery rate is same for $\gamma$ both transmission dynamics in Mainland China and in Hong Kong.

\section{Effective reproductive number calculation}

The effective reproductive number $R_{e}$, was calculated using the next-generation matrix approach after obtaining the posterior distributions of model parameters. Following the same notation as in the study by Diekmann et al[2]. We obtained the transmission matrix $T$ and the transition $S$. Elements in $T$ represents the average newly infected cases in exposed group (E) transmitted by a single infected individual in infectious or quarantined group (I), which can be calculated as $\beta \frac{S}{N}$ or $q \beta \frac{S}{N}$. $R_{e}$ can be calculated as the first eigenvector of $-\left(T S^{-1}\right)$ with the following formulas:

$$
\begin{gathered}
T=\left[\begin{array}{ccc}
0 & \beta \frac{S}{N} & q \beta \frac{S}{N} \\
0 & 0 & 0 \\
0 & 0 & 0
\end{array}\right] \\
S=\left[\begin{array}{ccc}
\frac{-1}{\tau} & 0 & 0 \\
\frac{1}{\tau} & -\left(\frac{1}{T_{c}}+\frac{1}{T_{q r}}\right) & 0 \\
0 & \frac{1}{T_{q r}} & \frac{-1}{T_{c}}
\end{array}\right]
\end{gathered}
$$


medRxiv preprint doi: https://doi.org/10.1101/2020.04.09.20059006; this version posted April 11, 2020. The copyright holder for this preprint (which was not certified by peer review) is the author/funder, who has granted medRxiv a license to display the preprint in perpetuity.

It is made available under a CC-BY-ND 4.0 International license .

\section{Supplementary Figures and Tables}
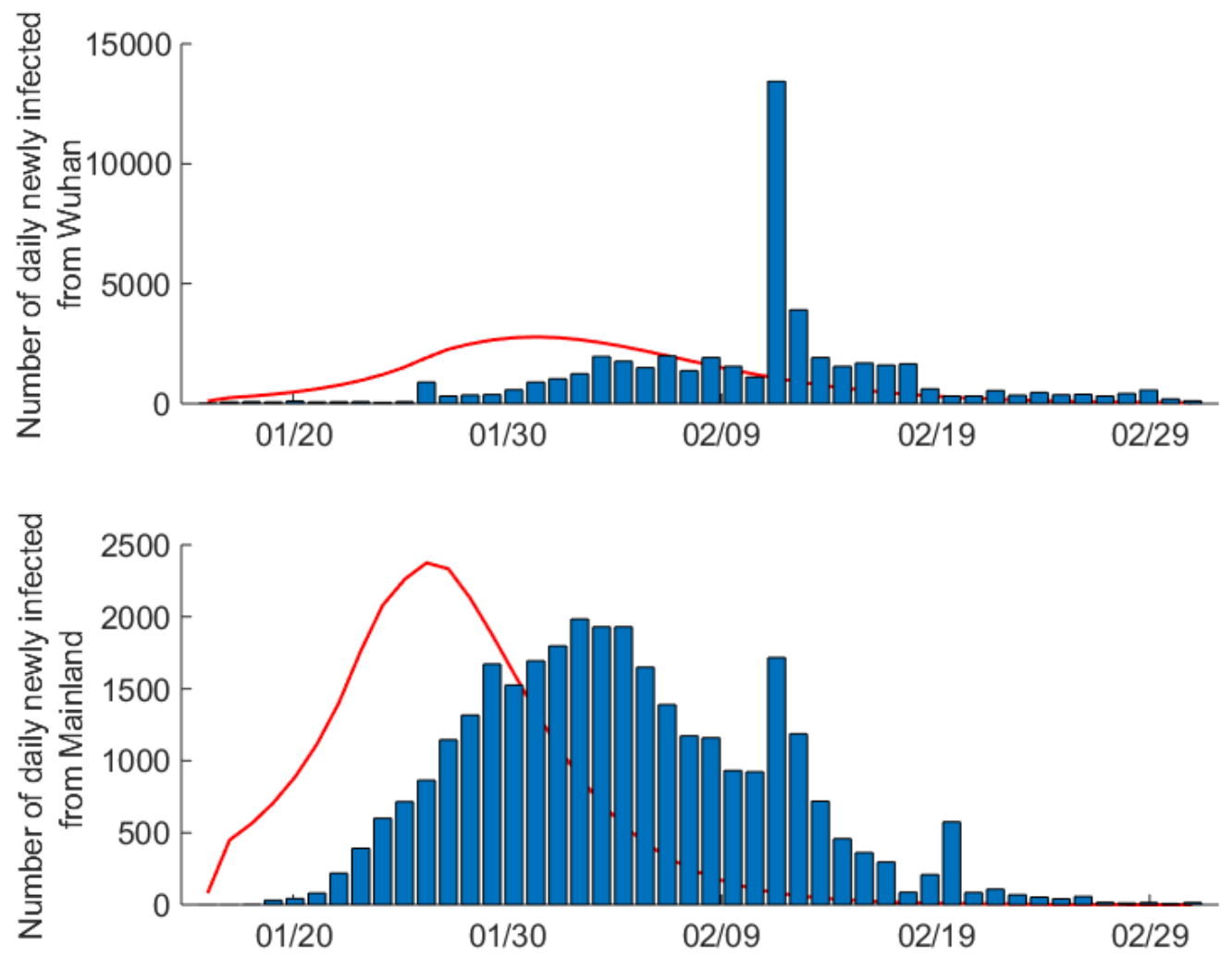

Figure S1 The number of daily newly infected COVID-19 cases by onset day in China. (A) Daily newly infected COVID-19 cases in Wuhan, China. Red line represents the reconstructed curve adjusted by 10 days reporting delay after fitting the actual data in Wuhan. The x-axis denotes the case reporting day after Jan 16, 2020. (B) Daily newly infected COVID-19 cases in Mainland China (outside Wuhan). Red line represents the reconstructed curve adjusted by 10 days reporting delay after fitting the actual data outside Wuhan. 
medRxiv preprint doi: https://doi.org/10.1101/2020.04.09.20059006; this version posted April 11, 2020. The copyright holder for this preprint (which was not certified by peer review) is the author/funder, who has granted medRxiv a license to display the preprint in perpetuity.

It is made available under a CC-BY-ND 4.0 International license .
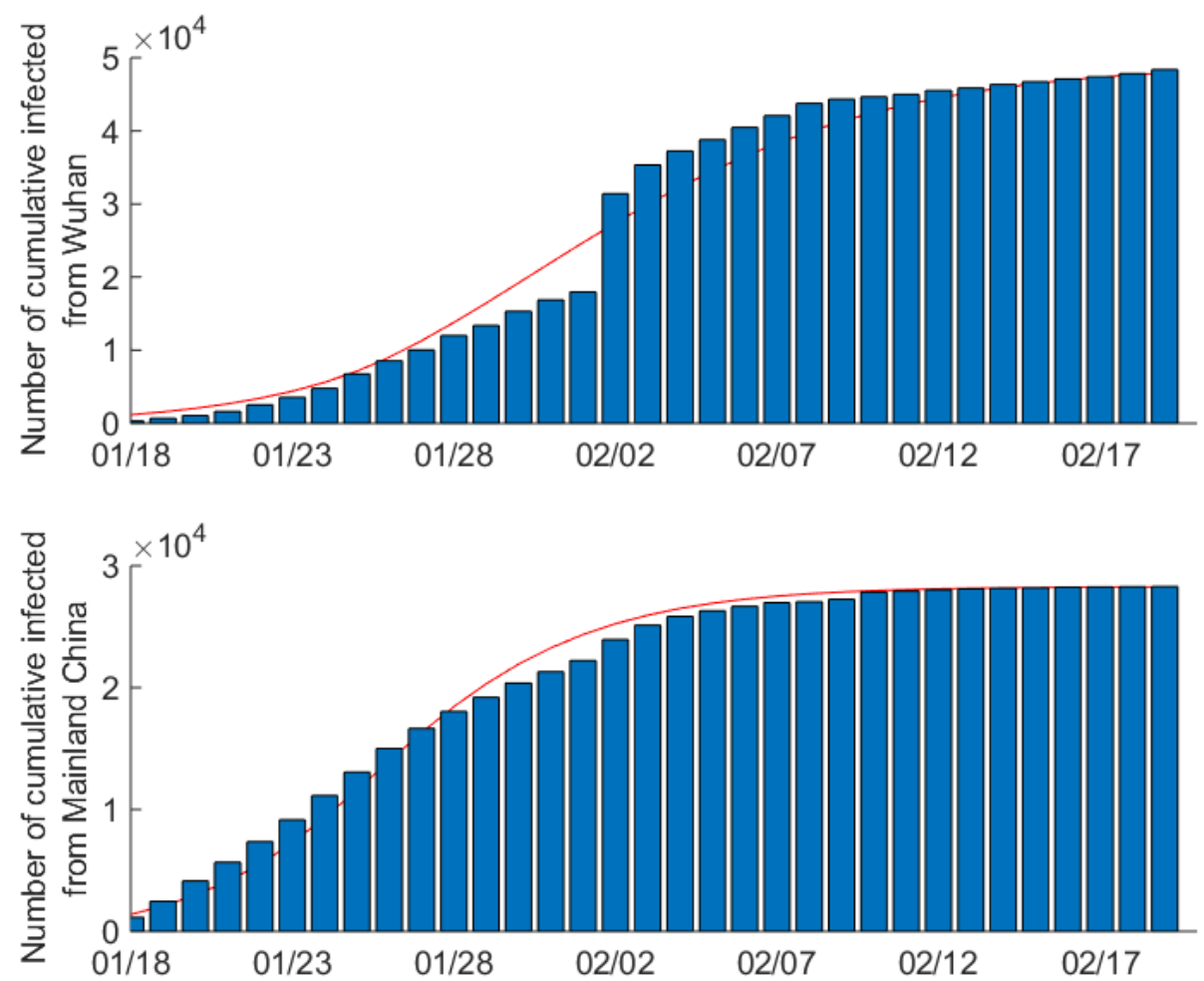

Figure S2 The number of cumulative confirmed COVID-19 cases by onset day in China. (A) Cumulative confirmed COVID19 cases in Wuhan, China. Red line represents the reconstructed curve adjusted by 10 days reporting delay after fitting the actual data inside Wuhan. The x-axis denotes the number of days from Jan 18 to Feb 29, 2020. (B) Cumulative confirmed COVID-19 cases in Mainland China (outside Wuhan). Red line represents the reconstructed curve adjusted by 10 days reporting delay after fitting the actual data outside Wuhan. 
medRxiv preprint doi: https://doi.org/10.1101/2020.04.09.20059006; this version posted April 11, 2020. The copyright holder for this preprint (which was not certified by peer review) is the author/funder, who has granted medRxiv a license to display the preprint in perpetuity. It is made available under a CC-BY-ND 4.0 International license .
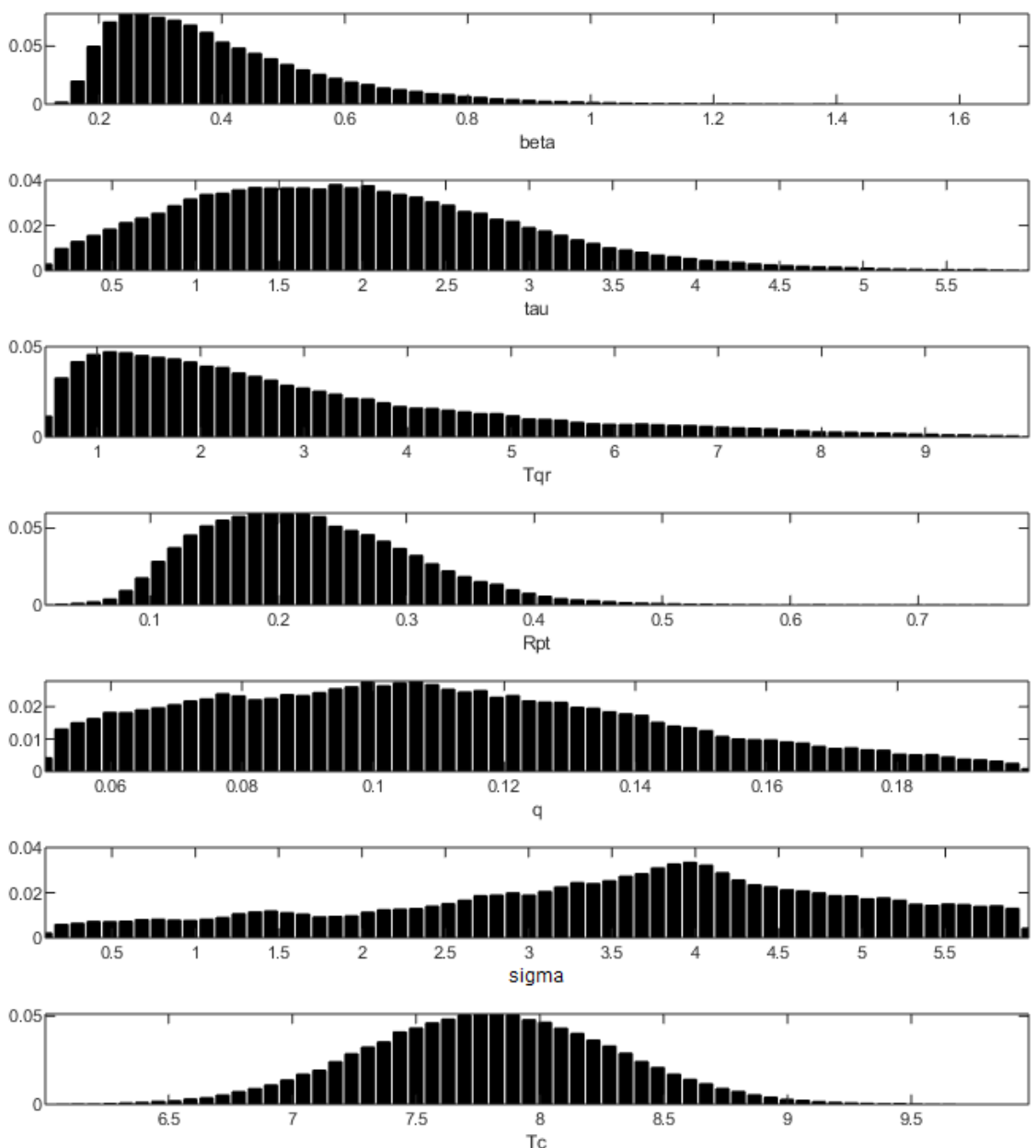

Figure S3 Posterior distributions of model parameters. 

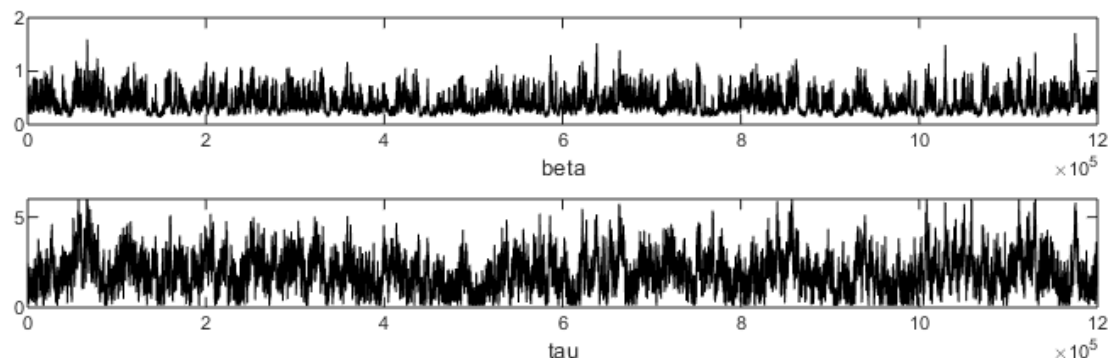

tau
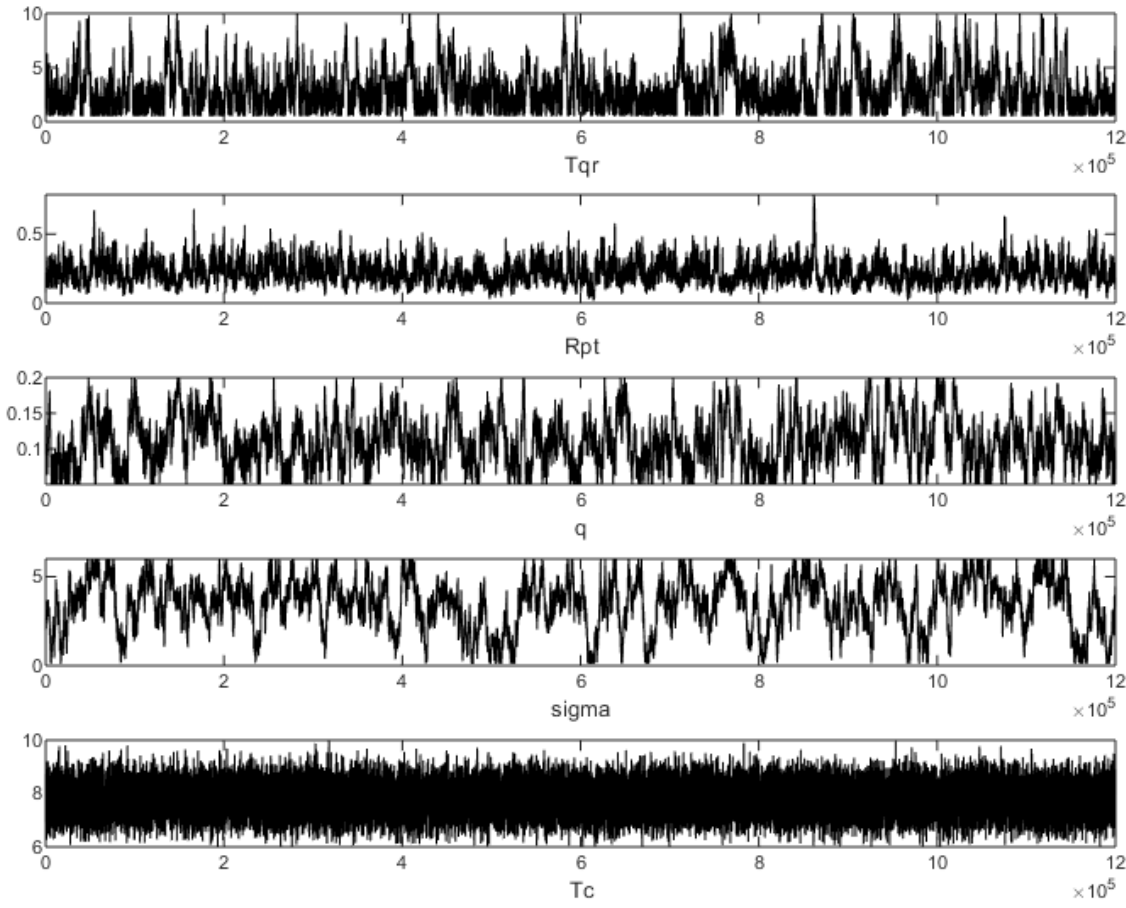

Figure S4 Trajectories of MCMC output. 
medRxiv preprint doi: https://doi.org/10.1101/2020.04.09.20059006; this version posted April 11, 2020. The copyright holder for this preprint (which was not certified by peer review) is the author/funder, who has granted medRxiv a license to display the preprint in perpetuity.

It is made available under a CC-BY-ND 4.0 International license .

Table S1 Daily number of passengers from outside Hong Kong

\begin{tabular}{|c|c|c|c|c|c|}
\hline Time & Residents(HK) & Residents(Mainland) & Time & Residents(HK) & Residents(Mainland) \\
\hline $1 / 24$ & 102,663 & 36,705 & $2 / 12$ & 15,792 & 729 \\
\hline $1 / 25$ & 86,417 & 29,891 & $2 / 13$ & 13,312 & 751 \\
\hline $1 / 26$ & 163,668 & 36,690 & $2 / 14$ & 13,507 & 683 \\
\hline $1 / 27$ & 177,470 & 28,780 & $2 / 15$ & 16,089 & 791 \\
\hline $1 / 28$ & 188,788 & 24,156 & $2 / 16$ & 20,325 & 749 \\
\hline $1 / 29$ & 197,572 & 27,780 & $2 / 17$ & 15,990 & 643 \\
\hline $1 / 30$ & 132,506 & 19,555 & $2 / 18$ & 14,383 & 579 \\
\hline $1 / 31$ & 116,544 & 16,058 & $2 / 19$ & 12,801 & 567 \\
\hline $2 / 1$ & 115,122 & 13,382 & $2 / 20$ & 13,677 & 648 \\
\hline $2 / 2$ & 122,399 & 11,715 & $2 / 21$ & 14,557 & 682 \\
\hline $2 / 3$ & 111,033 & 13,461 & $2 / 22$ & 15,440 & 651 \\
\hline $2 / 4$ & 54,816 & 9,511 & $2 / 23$ & 20,241 & 673 \\
\hline $2 / 5$ & 44,566 & 8,760 & $2 / 24$ & 16,972 & 588 \\
\hline $2 / 6$ & 65,122 & 11,009 & $2 / 25$ & 15,207 & 558 \\
\hline $2 / 7$ & 76,899 & 12,746 & $2 / 26$ & 14,317 & 587 \\
\hline $2 / 8$ & 18,823 & 995 & $2 / 27$ & 13,846 & 702 \\
\hline $2 / 9$ & 24,939 & 956 & $2 / 28$ & 15,248 & 558 \\
\hline $2 / 10$ & 18,408 & 832 & $2 / 29$ & 17,881 & 1,084 \\
\hline $2 / 11$ & 15,953 & 738 & & & \\
\hline
\end{tabular}


medRxiv preprint doi: https://doi.org/10.1101/2020.04.09.20059006; this version posted April 11, 2020. The copyright holder for this preprint (which was not certified by peer review) is the author/funder, who has granted medRxiv a license to display the preprint in perpetuity. It is made available under a CC-BY-ND 4.0 International license .

\section{References}

[1] “https://www.news.gov.hk/eng/2020/02/20200207/20200207_185633_805.html,” Hong Kong Government. Arrivals down. .

[2] Q. Li et al., "Early Transmission Dynamics in Wuhan, China, of Novel Coronavirus-Infected Pneumonia," N. Engl. J. Med., pp. 1199-1207, 2020. 